\title{
THE IMPACT OF POSITIVE ACCELERATION (+GZ) ON ANTIOXIDANT CAPACITY AND HISTOPATHOLOGICAL ALTERATIONS IN DIFFERENT ORGANS AND TISSUES IN RATS
}

Jelena Ristic ${ }^{1}$, Tamara Nikolic ${ }^{2}$, Jovana Jeremic ${ }^{2}$, Isidora Stojic ${ }^{2}$, Snezana Janicijevic-Hudomal ${ }^{3}$, Mira Popovic ${ }^{4}$,

Gordana Arsic-Komljenovic ${ }^{5}$, Radmila Radojevic-Popovic ${ }^{6}$, Ivan Srejovic ${ }^{7}$ and Vladimir Zivkovic ${ }^{7}$

${ }^{1}$ Richter Gedeon Representative Office for Serbia, Belgrade, Serbia

${ }^{2}$ Department of Pharmacy, Faculty of Medical Sciences, University of Kragujevac, Serbia

${ }^{3}$ Department of Pharmacology, Medical Faculty, University of Pristina, Kosovska Mitrovica Serba

${ }^{4}$ Department of Chemistry, Faculty of Sciences, University of Novi Sad, Novi Sad, Serbia

${ }^{5}$ High Medical College of Professional Studies "Milutin Milankovic", Belgrade, Serbia ${ }^{6}$ Special Hospital for Hyperbaric Medicine, Belgrade, Serbia

${ }^{7}$ Department of Physiology, Faculty of Medical Sciences, University of Kragujevac, Serbia

\author{
UTICAJ POZITIVNOG UBRZANJA (+GZ) NA ANTIOISIDATIVNI \\ KAPACITET I HISTOPATOLOŠKE PROMENE NA RAZLIČITIM \\ ORGANIMA I TKIVIMA PACOVA \\ Jelena Ristić1, Tamara Nikolić2, Jovana Jeremić2, Isidora Stojić2, Snežana Janićijević-Hudomal3, Mira Popović4, \\ Gordana Arsić-Komljenović 5, Radmila Radojevic-Popovic6, Ivan Srejović7 i Vladimir Živković7 \\ 1Richter Gedeon Predstavništvo za Srbiju, Beograd, Srbija \\ 2Katedra za farmaciju, Fakultet medicinskih nauka, Univerzitet u Kragujevcu, Srbija \\ 3Katedra za farmakologiju, Medicinski fakultet, Univerzitet u Prištini, Kosovska Mitrovica, Srbija \\ 4Katedra za hemiju, Prirodno-matematički fakultet, Univerzitet u Novom Sadu, Novi Sad, Srbija \\ 5Visoka medicinska škola strukovnih studija "Milutin Milanković", Beograd, Srbija \\ 6Specijalna bolnica za hiperbaričnu medicinu, Beograd, Srbija \\ 7Katedra za fiziologiju, Fakultet medicinskih nauka, Univerzitet u Kragujevcu, Kragujevac, Srbija
}

Received / Primljen: 12. 08. 2016.

Accepted / Prihvaćen: 23. 09. 2016.

\begin{abstract}
Since the early 1940s, a significant amount of research has been conducted to describe the impact of the high-G acceleration on the cardiovascular system. The objective of the present study was to examine the role of the antioxidant enzyme system under biodynamic stress in the liver, heart and gastric mucosa in response to high-magnitude $+\mathrm{Gz}$ exposure in a rat model. Twenty adult male Wistar albino rats (10 rats per group; 9-11 weeks old, 200-250 g b.w.) were divided into the following two groups: control and $G$ (exposed to a biodynamic stress model under positive $(+7 \mathrm{Gz})$ acceleration for $40 \mathrm{~s}$ ). The influence of acute biodynamic stress on pro-oxidative parameters in the rat liver (xanthine oxidase $(X O D)$, catalase (CAT), peroxidase (Px), glutathione peroxidase (GSH-Px), total content of glutathione (GSH), lipid peroxidation $(L P x)$ ) and on histopathological alterations in the liver, cardiac muscle and gastric mucosa was examined. Biodynamic stress resulting from positive $(+7 \mathrm{Gz})$ acceleration resulted in a highly statistically significant increase of CAT GSH-Px activity compared to the control group. The LPx levels were significantly decreased, but the GSH contents and the activities of other enzymes were not significantly changed. Significant microscopic changes in the liver, heart and gastric mucosa were observed in the G group. These results clearly indicate that $+G z$ acceleration alters biochemical systems. These alterations in cellular processes may be mediated by influences of hypoxia or ischaemia via changes in the antioxidant capacity.
\end{abstract}

Keywords: $+G z$ acceleration, antioxidant enzyme, liver, heart, gastric mucosa, rats

\section{SAŽETAK}

Od ranih 1940-ih, značajan broj istraživanja je sproveden u pokušaju da se opiše uticaj visokog G ubrzanja na kardiovaskularni sistem. Cilj naše studije je bio da ispita ulogu sistema antioksidativne zaštite u stanju biodinamičkog stresa u jetri, srcu i gastričnoj mukozi, prouzrokovanog izlaganjem visokim vrednostima +Gzna modelu pacova. Koristili smo 20 odraslih Wistar albino pacova muškog pola, (10 po grupi; starosti 9-11 nedelja, telesne mase 200-250g) podeljenih u kontrolnu grupu $i \mathrm{G}$ grupu (izloženi modelu biodinamičkog stresa pozitivnom (+7Gz)ubrzanju tokom 40s). Ispitivali smo uticaj akutnog biodinamičkog stresa na prooksidativne parametre u jetri pacova (oksidaza (ksantin XOD), katalaza (CAT), peroksidaza (Px), glutation peroksidaza (GSH-Px), ukupan sadržaj glutationa (GSH), lipidna peroksidacija (LPx)) i na histopatološke promene u jetri, srčanom mišiću i gastričnoj mukozi. Biodinamički stres uzrokovan pozitivnim ubrzanjem $(+7 \mathrm{Gz})$ je izazvao visoko statistički značajno povećanje aktivnosti CAT u poredenju sa kontrolnom grupom, kao i aktivnosti GSH-Px. Nivo LPx se značajno smanjio, ali sadržaj GSH $i$ aktivnost ostalih enzima se nije značajno promenio. U G grupi otkrili smo značajne mikroskopske promene u jetri, srcu i gastričnoj mukozi. Naši rezultati jasno ukazuju na to da + Gz ubrzanje ima sposobnost da promeni biohemijske sisteme. Ove promene u ćelijskim procesima mogu biti posredovane uticajima hipoksije ili ishemije, menjajući antioksidativni kapacitet.

Ključne reči: +Gz ubrzanje, antioksidativni enzimi, jetra, srce, gastrična mukoza, pacovi 


\section{ABBREVIATIONS}

G force - ratio given acceleration/due to gravity $+\mathbf{G z}$ - inertial force that acts from head to feet (positive)

CAT - catalase GSH - reduced glutathione GSH-Px - glutathione peroxidase GSSG - oxidized glutathione
XOD - xanthine oxidase

$\mathbf{P x}$ - peroxidase

LPX - lipid peroxidation

EDTA - ethylenediaminetetraacetic acid

TRIS - Tris(hydroxymethyl)aminomethane

MDA - malondialdehyde

ROS - reactive oxygen species

\section{INTRODUCTION}

Reflecting improvements in the aviation industry, highly manoeuvrable aircrafts have been introduced to military aviation worldwide. Since the early 1940s, several research studies been conducted to describe how acute high-G acceleration exposure affects cerebral perfusion, regulatory cardiovascular mechanisms and consciousness in high-performance aircraft pilots during aerial combat manoeuvres (1).

The pilots of these aircraft are exposed to acceleration forces (particularly $+\mathrm{Gz}$ ) at higher magnitudes and for longer durations. "G" is a measure of the force experienced by a person due to acceleration, expressed in terms of multiples of the Earth's gravitational acceleration. $+\mathrm{Gz}$ is a description of the $G$ vector in which the vertical ( $\mathrm{z}$ ) axis is parallel to the long spinal axis of the body, and the direction (+) is from head to foot. The G capability of a modern aircraft is high, but the $G$ tolerance of a human organism is limited. The human body acclimates to conditions of high acceleration forces through physiological compensation mechanisms (2).

Repeated exposure to high $+\mathrm{Gz}$ can induce significant physiological adaptation reactions associated with blood pressure regulation (blood volume reduction and decreased cardiac output) (3). In addition, cardiomyocytes and muscle fibres become damaged as a result of mechanical force and severe haemodynamic changes. The exposure of the human body to $+\mathrm{Gz}$ acceleration produces dramatic effects on the cardiovascular system (4). For example, during $+\mathrm{Gz}$ stress, the heart rate has been reported to increase in excess of $200 \mathrm{~b} / \mathrm{min}^{-1}$, and the left ventricular pressure has been estimated to reach $300 \mathrm{~mm} \mathrm{Hg}$. Several reviews concerning the overall effects of $+\mathrm{Gz}$ stress on the cardiovascular system have been published (5). Acceleration on the $+\mathrm{Gz}$ axis increases pressure in the cardiac chambers. Some authors have confirmed that the effects of high $+\mathrm{Gz}$ were similar to the haemodynamic changes and redox imbalance observed in ischaemia reperfusion (I/R) (6).

Other consequences of $+\mathrm{Gz}$ positive acceleration have also been described. Several studies have demonstrated that $+\mathrm{Gz}$ affects many organs, such as the lungs, liver, bones and kidneys, and even consciousness and acute gastric mucosal injury have also been observed. However, the effect of the exposure of pre-existing gastric mucosa injuries to $+\mathrm{Gz}$ conditions has not been extensively examined (4-8).
The normal weight, hydrostatic pressure and physiological ventilation/perfusion gradients in the lungs are exaggerated under high $+\mathrm{Gz}$ forces, resulting in increased pulmonary arterio-venous shunting (5-7), which leads to the impairment of circulatory oxygenation and may also result in acceleration-induced atelectasis. Moreover, the effects of $+\mathrm{Gz}$ acceleration forces on brain damage as a result of ischaemia and hypoxia and the limitations of the cervical musculature have been described. The liver is the largest internal organ and plays an important role in metabolism. In experimental studies, repeated $+\mathrm{Gz}$ exposure can transiently cause liver dysfunction and trigger pathological changes (5-8).

Furthermore, $+\mathrm{Gz}$ exposure likely induces accumulative stress damage in the body, inducing organ dysfunction and triggering pathological changes and the activation of the biological defence system, including antioxidant and immune functions $(7,8)$. Oxidative stress is defined as an imbalance between the production and removal of reactive oxygen species (ROS), which could lead to cell damage and cell death (9). However, the activation of antioxidative processes induced by ROS likely inhibits several types of oxidative damage $(10,11)$.

However, the mechanisms underlying injuries to the heart and other organs under high $+\mathrm{Gz}$ stress have not been systematically studied. The objective of the present study was to investigate the role of the antioxidative enzyme system in the liver, heart and gastric mucosa under biodynamic stress induced through high-magnitude $+\mathrm{Gz}$ exposure in a rat model.

\section{MATERIALS AND METHODS}

\section{Experimental protocol}

The present study used 20 adult male Wistar albino rats, 9-11 weeks old, weighing 200-250 grams, which were specially bred in a vivarium at The Center for Scientific Research ICN Galenika, Belgrade. Before seeing, rats (4-6 animals) have stayed in standard Plexiglas cages, in a room with controlled temperature of $22 \pm 1^{\circ} \mathrm{C}$, relative humidity 
(65-70\%) and day/night cycle (12:12 brightness / darkness). The rats were fed with standard food dedicated for laboratory rats. All research procedures were performed in accordance with the European Directive for the Welfare of Laboratory Animals (No 86/609/EEC) and the principles of Good Laboratory Practice (GLP).

All animals were divided into 2 groups (10 rats per group): C group (healthy animals without exposure to $+\mathrm{Gz}$ acceleration) and $\mathrm{G}$ group (animals exposed to positive (+7 $\mathrm{Gz}$ ) acceleration).

In the present study, we examined the influence of acute biodynamic stress $(+7 \mathrm{Gz})$ on the dynamics of the parameters of oxidative stress in the liver, such as the activities of xanthine oxidase (XOD), catalase (CAT), peroxidase $(\mathrm{Px})$, and glutathione peroxidase (GSH-Px), the total contents of glutathione (GSH) and lipid peroxidation (LPx) and the histopathological alterations in the liver, cardiac muscle and the gastric mucosa.

\section{$+G z$ stress exposure}

Biodynamic stress through positive $(+\mathrm{Gz})$ acceleration in gravity-altitude laboratories (CFC-35 centrifuge) was used to induce acute stress. The experimental animals were subjected to growing linear acceleration tests at increments from $0.1 \mathrm{G} / \mathrm{s}$ to $+7 \mathrm{Gz}$ in the gravity-altitude laboratories (centrifuge) of the Institute of Aviation Medicine, Military Academy in Belgrade, Serbia.

Prior to the growing linear acceleration tests, all animals were fasted (without food) for 24 hours in individual metabolic cages to prevent coprophagia. The centrifuge type-CFC-35 comprises two branches with cabins on both sides (for both humans and animals). These arms, which are attached to the pivot, around which rotation is made, are 9 metres in size. Positive $(+\mathrm{Gz})$ acceleration was produced by the position of weights attached below the vertical axis of the cabin. A centrifuge has a maximum acceleration of $35 \mathrm{G}(\mathrm{x}, \mathrm{y}, \mathrm{z})$ with an acceleration weight gain of $0.1 \mathrm{G} / \mathrm{s}$. A programmer managed the centrifuge either manually or automatically. After fixation of the cage in the centrifuge cabin intended for animal experiments, the animals were exposed to positive linear acceleration $(+7 \mathrm{Gz})$ for $40 \mathrm{~s}$.

Thirty minutes after the centrifuge test, all rats were euthanized by decapitation. The chest and stomach were quickly opened, and the hearts, livers and gastric samples were harvested, repeatedly flushed with $0.9 \%$ saline, and stored at $-80^{\circ} \mathrm{C}$.

Tissue preparation for the determination of enzyme activity in the liver (GSH, GSH-Px, CAT, Px, XOD, and LPX)

Whole livers were isolated from the rats, and the tissues were homogenized in cold phosphate buffer ( $\mathrm{pH}$ 8.0). The final tissue concentration in the tissue homogenate was 20 mg of tissue per $\mathrm{ml}$ of buffer (12). The liver tissue homogenates were used to determine the levels of enzymes, such as GSH, GSH-Px, CAT, Px, XOD and LPx.

\section{Determination of reduced glutathione (GSH) content}

The GSH content in the homogenates was determined as the amount of non-protein residues using -SH Ellman's reagent according to Benzie et al (13). To determine the GSH content in the homogenate, $1 \mathrm{ml}$ of the homogenate was centrifuged in $2 \mathrm{~mL}$ of sulfosalicylic acid (4\%) for 10 $\mathrm{min}$ at $3000 \mathrm{bmp} / \mathrm{min}$. Subsequently, $0.05 \mathrm{ml}$ of the supernatant was mixed with $2 \mathrm{ml}$ of Ellman's reagent, and the absorbance was measured at $412 \mathrm{~nm}$. The GSH content was calculated from the molar ratio and converted to per mg of protein over total protein.

\section{Determination of glutathione peroxidase (GPx) activity}

The activity of glutathione peroxidase was determined using cumene hydroperoxide according to Flohe et al (14, 15). To this end, $0.05 \mathrm{ml}$ of the homogenate was mixed with $0.75 \mathrm{ml}$ of $50 \mathrm{mmol} / \mathrm{dm}^{3}$ Tris- $\mathrm{HCl}$ buffer, $\mathrm{pH} 7.6$ (Buffer 1), and controlled using a thermostat for $10 \mathrm{~min}$ at $37^{\circ} \mathrm{C}$. Subsequently, $0.1 \mathrm{ml} \mathrm{GSH}(0.006 \mathrm{~g}$ in $10 \mathrm{ml}$ of Buffer 1) was added to the control sample, and $0.1 \mathrm{ml} \mathrm{GSH}$ and $0.1 \mathrm{ml}$ of cumyl hydroperoxide $(0.05 \mathrm{ml}$ in $10 \mathrm{ml} \mathrm{MeOH})$ was added to the experimental sample, and both samples were incubated at $37^{\circ} \mathrm{C}$ for 5 minutes. Subsequently, the probe was added to $1 \mathrm{ml}$ TCA (20\%) for both samples, and $0.1 \mathrm{ml}$ of cumyl hydroperoxide was added to the control. The cooled solution was centrifuged at $3000 \mathrm{bmp} / \mathrm{min}$ for $10 \mathrm{~min}$. A total of $2 \mathrm{ml}$ of a $0.4 \mathrm{M}$ Tris- $\mathrm{HCl}$ buffer, $\mathrm{pH} 8.9$ (Buffer 2) and $0.1 \mathrm{ml}$ DTNB (0.02 g in $5 \mathrm{ml}$ of Buffer 2) was added to 1-ml samples of the supernatant of each probe, and the absorbance was measured at $412 \mathrm{~nm}$. The results are expressed in $\mathrm{nmol} / \mathrm{mg}$ protein $/ \mathrm{min}\left(\varepsilon=1.36 \times 10^{4} \mathrm{dm}^{3}\right.$ $\left.\mathrm{mol}^{-1} \mathrm{~cm}^{-1}\right)$.

\section{Determination of catalase (CAT) activity}

Catalase activity was determined using hydrogen peroxide as a substrate according to Viviez-Bauza et al (16). A total of $3 \mathrm{ml}$ of substrate $(50 \mathrm{mM}$ phosphate buffer, $p \mathrm{H}$ $7,0.075 \mathrm{ml}$ of $30 \% \mathrm{H}_{2} \mathrm{O}_{2}$ per $50 \mathrm{ml}$ of $\mathrm{KPi}$ ) was added to 20 $\mu \mathrm{l}$ of homogenate. The absorbance was measured at 240 $\mathrm{nm}$, and the results are expressed in $\mathrm{nmol} / \mathrm{mg}$ protein $/ \mathrm{min}$ $\left(\varepsilon=4.36 \times 10^{4} \mathrm{dm}^{3} \mathrm{~mol}^{-1} \mathrm{~cm}^{-1}\right)$.

\section{Determination of peroxidase (Px) activity}

The peroxidase activity was determined using hydrogen peroxide as a substrate according to Bergmayer et al $(17,18)$. To this end, $3 \mathrm{ml}$ of phosphate buffer $\left(0.1 \mathrm{~mol} \mathrm{dm}^{-}\right.$ ', $\mathrm{pH} 7$ ), $50 \mu \mathrm{l}$ of guaiacol (250 $\mathrm{g}$ in $100 \mathrm{ml}$ of $\mathrm{H}_{2} \mathrm{O}$ ) and 40 $\mu \mathrm{l}$ of hydrogen peroxide $\left(140 \mu \mathrm{l}\right.$ of $30 \% \mathrm{H}_{2} \mathrm{O}_{2}$ in $100 \mathrm{ml}$ of $\mathrm{H}_{2} \mathrm{O}$ ) were added to $50 \mu \mathrm{l}$ of homogenate, and the absorbance of the reaction product was measured at $436 \mathrm{~nm}$. The results are expressed in $\mathrm{nmol} / \mathrm{mg}$ protein $/ \mathrm{min}(\varepsilon=$ $\left.2.3 \times 10^{4} \mathrm{dm}^{3} \mathrm{~mol}^{-1} \mathrm{~cm}^{-1}\right)$. 


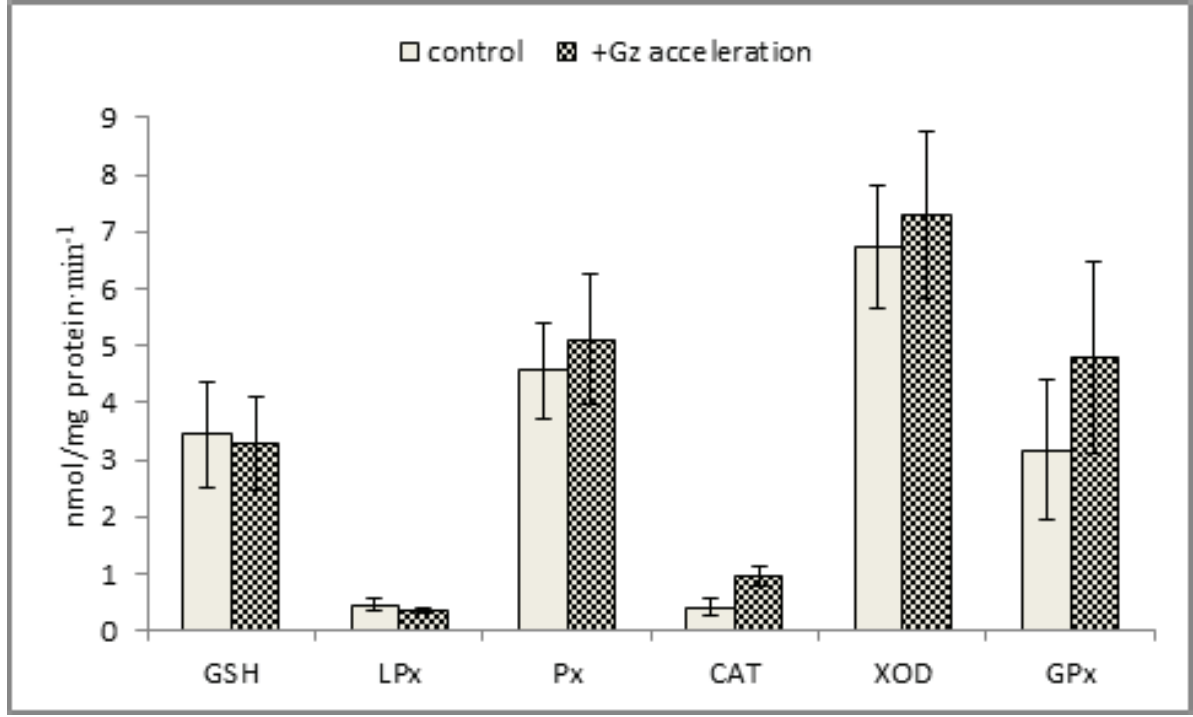

Fig. 1 - Changes in the parameters of oxidative stress in the livers of animals in the G group compared to the control group exhibited a positive $(+7 \mathrm{Gz})$ acceleration. CAT activity, Px and GSH-Px are expressed in $\mathrm{nmol} / \mathrm{mg}$ protein $\cdot \mathrm{min}^{-1}$; XOD activity is expressed in $\mathrm{mmol} / \mathrm{mg}$ protein $\cdot \mathrm{min}^{-1}$; LPx intensity expressed as nmol of malondialdehyde/mg protein; GSH content is expressed as GSH nmol/mg protein. The values are presented as the means $\pm \mathrm{SD}\left({ }^{*}=\mathrm{p}<0.05 ;{ }^{* * * *}=\mathrm{p}<0.01\right)$.

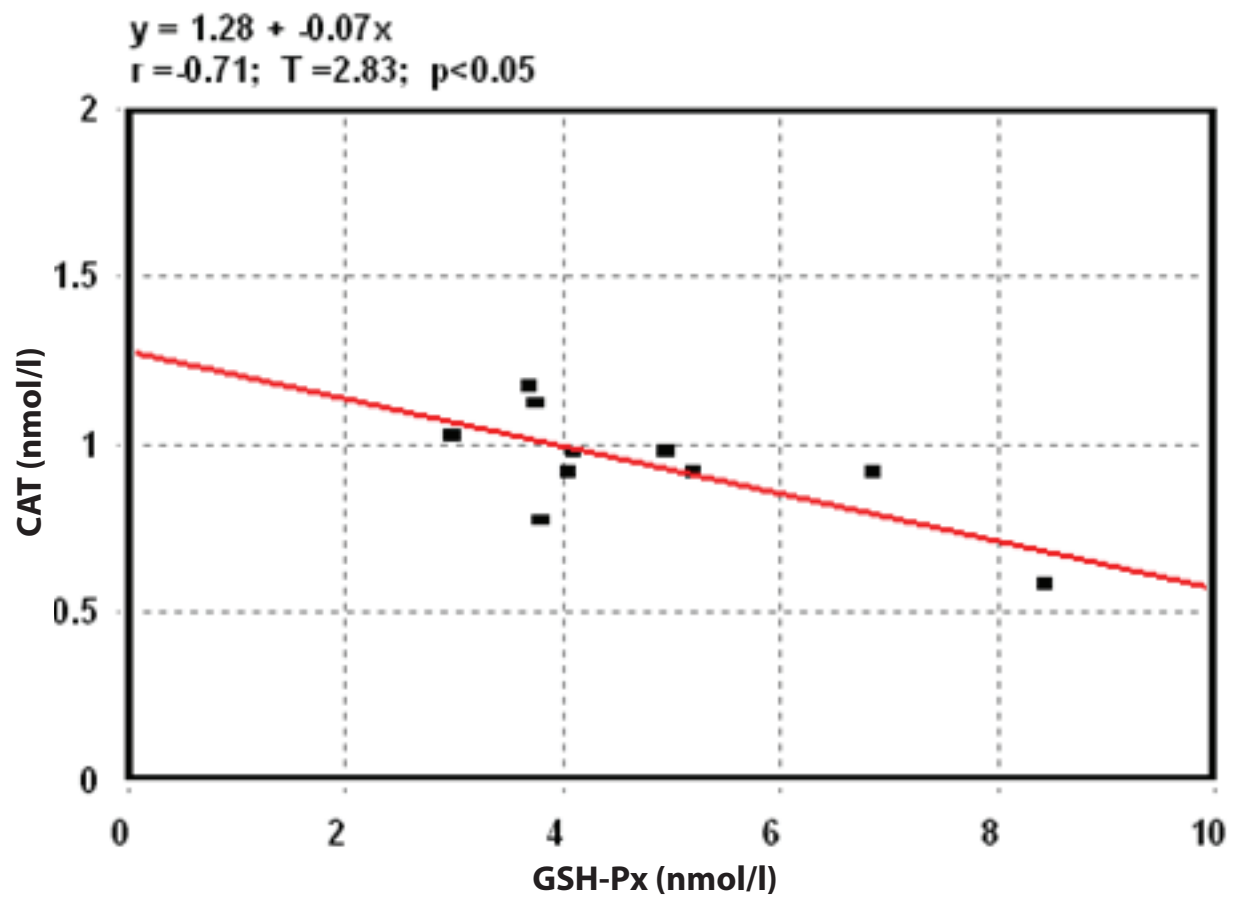

Fig. 2 - Correlation between CAT and GSH-Px activity in the experimental group (G group) $(\mathrm{r}=-0.71)$

\section{Determination of xanthine oxidase (XOD) activity}

The activity of XOD was spectrophotometrically determined by varying the optical density at $293 \mathrm{~nm}$ after passing hypoxanthine to uric acid, according to Bergmayer et al $(18,19)$. A total of $3 \mathrm{~cm}^{3}$ of $0.05 \mathrm{~mol} / \mathrm{dm}^{3}$ potassium phosphate with $p \mathrm{H}=7.5$, containing the EDTA and hypoxanthine, at a concentration of $1 \mathrm{mmol} / \mathrm{dm}^{3}$, was added to 30 $\mu \mathrm{l}$ of liver homogenate or $100 \mu \mathrm{l}$ of haemolysate. The solution was centrifuged at $3000 \mathrm{bmp} / \mathrm{min}$ for $10 \mathrm{~min}$. Finally, the absorbance of the reaction product was measured at $293 \mathrm{~nm}$, and the results are expressed in $\mu \mathrm{mol} / \mathrm{g}$ of liver or $\mu \mathrm{mol} \mathrm{min} / \mathrm{mg}$ protein $/ \mathrm{min}\left(\varepsilon=1.2 \times 10^{4} \mathrm{dm}^{3} \mathrm{~mol} / \mathrm{cm}\right)$.

Index of lipid peroxidation measured as the Malondialdehyde (MDA) concentration

The malondialdehyde (MDA) concentration was determined using the thiobarbituric acid method according to Halliwell et al (20), wherein lipid oxidation is measured by 
the cell membrane via the lipid-peroxide reaction products formed in a reaction system using thiobarbituric acid. A total of $0.5 \mathrm{ml}$ of homogenate was heated for 15 minutes in a water bath and subsequently added to a solution of $3 \mathrm{~mL}$ of thiobarbituric acid $0.375 \%$ to $15 \%$ TCA $(3.75 \mathrm{~g}$ TBA $+15+20.72 \mathrm{~g}$ of $\mathrm{CCl}_{3} \mathrm{COOH} \mathrm{mL}$ of $37 \% \mathrm{HCl}+1-2$ drops of $\alpha$-tocopherol per 1 $\mathrm{dm}^{3}$ solution). The solution was subsequently centrifuged for 10 minutes at $3000 \mathrm{bmp} / \mathrm{min}$, and the absorbance of the resulting reaction product was measured at $535 \mathrm{~nm}$. The results are expressed as nmol of malondialdehyde/mg of protein $/ \mathrm{min}$ $\left(\varepsilon=1.56 \times 10^{5} \mathrm{dm}^{3} \mathrm{~mol}^{-1} \mathrm{~cm}^{-1}\right)$.

HEE staining of paraffin-embedded tissues and detection of microscopic changes

Macroscopic and microscopic changes in the heart, liver and gastric tissues were observed in control and experimental groups. For histological processing, heart, liver and gastric mucosa samples were prepared using standard techniques $(21,22)$. The specimens were fixed in $4 \%$ paraformaldehyde, dehydrated, embedded in paraffin, sectioned on a sliding microtome at 4-6 microns thick, and subsequently stained with haematoxylin-eosin (H\&E). Histological samples were analysed using a Leica DML type $S 2$ light microscope, harbouring a specific change in the photodocumented type of Canon Power Shot 570 digital camera $(21,22)$.

In the experimental group, we observed and recorded every alteration of the gastric mucosa using a magnifying glass (3x zoom, Luxo Magnifier). The sizes of all changes were expressed in $\mathrm{mm}$ and documented using an Olympus C350 type digital photo camera.

\section{Ulcer index of gastric mucosa}

The ulcer index was recorded and calculated using Guth's method. Ulcer length $\leq 1 \mathrm{~mm}$ (including erosion foci) was scored as $1 ; 1 \mathrm{~mm}<$ ulcer length $<2 \mathrm{~mm}$ was scored as 2; $2 \mathrm{~mm}<$ ulcer length $\leq 3 \mathrm{~mm}$ was scored as 3; $3 \mathrm{~mm}<$ ulcer length $\leq 4 \mathrm{~mm}$ was scored as 3 ; ulcer length
$>4 \mathrm{~mm}$ was scored as 5 ; and the score for ulcer width $>2$ mm was doubled (23).

\section{Statistical analysis}

All data are expressed as the means \pm standard deviation $(\mathrm{X} \pm \mathrm{SD})$. Data before and after $+\mathrm{Gz}$ stress exposure were evaluated using one-way analysis of variance (ANOVA) with the least significant difference (LSD) test for post hoc analysis. Correlations between all parameters were analysed using Pearson's correlation test. All analyses were performed using SPSS 13.0 (SPSS Inc., Chicago, Illinois, USA). P values $\leq 0.05$ were considered statistically significant.

\section{RESULTS}

\section{Biochemical data}

Biodynamic stress from positive $(+\mathrm{Gz})$ acceleration for 40 seconds led to a significant change in the activity of certain antioxidant enzymes in the liver in the experimental group compared to the control group. Biodynamic stress led to a highly statistically significant increase $(\mathrm{p}<0.01)$ of CAT activity compared to untreated animals (control group), in which the activity of CAT was decreased, and a statistically significant increase $(\mathrm{p}<0.05)$ in GSH-Px activity $(4.79$ $\pm 1.67)$ was observed compared to untreated animals $(3.17$ $\pm 1.23)$. The level of the LPx $(3.44 \pm 0.5)$ was significantly decreased $(\mathrm{p}<0.05)$ compared to control $(4.52 \pm 1: 05)$, but the content of GSH and the activities of other enzymes were not significantly changed. The levels of all enzymes examined in the $\mathrm{G}$ group of animals exposed to biodynamic stress by positive $(+\mathrm{Gz})$ acceleration, compared to the levels in the control group, are shown in Fig. 1. In the control group, Px activity was positively correlated with the levels of LPx $(\mathrm{r}=0.86 ; \mathrm{p}<0.001)$. In addition, XOD activity was positively correlated with the GSH content $(\mathrm{r}=0.90 ; \mathrm{p}<0.001)$ (Tables 1 and 2). Interestingly, in the $G$ group, which was exposed to positive $(+\mathrm{Gz})$ acceleration, the CAT activity was negatively correlated with the GSH-Px activity $(\mathrm{r}=0.71 ; \mathrm{p}<0.05)$ (Fig. 2).

Table 1 - The correlation matrix of parameters of oxidative stress in the livers of healthy animals (control group) $(* \mathrm{p}<0.05 ; * * * \mathrm{*}<0.01)$.

\begin{tabular}{|c|c|c|c|c|c|}
\hline Control group & $\begin{array}{l}\text { GSH (nmol/ } \\
\text { mg protein) }\end{array}$ & $\begin{array}{l}\mathrm{LPx}(\mathrm{nmol} / \mathrm{mg} \\
\text { protein) }\end{array}$ & $\begin{array}{l}\mathrm{Px}(\mathrm{nmol} / \mathrm{mg} \\
\left.\text { protein } \cdot \mathrm{min}^{-1}\right)\end{array}$ & $\begin{array}{c}\text { CAT } \\
\left(\mathrm{nmol} / \mathrm{mg}^{-1}\right) \\
\left.\text { protein } \mathrm{min}^{-1}\right)\end{array}$ & $\begin{array}{c}\text { XOD } \\
\left(\mu \mathrm{mol} / \mathrm{mg}^{-1}\right. \\
\left.\text { protein } \cdot \mathrm{min}^{-1}\right)\end{array}$ \\
\hline $\begin{array}{l}\text { LPx (nmol/mg } \\
\text { protein) }\end{array}$ & 0.34 & & & & \\
\hline $\begin{array}{l}\mathrm{Px}(\mathrm{nmol} / \mathrm{mg} \\
\left.\text { protein } \cdot \mathrm{min}^{-1}\right)\end{array}$ & 0.34 & $0.86^{* \% *}$ & & & \\
\hline $\begin{array}{l}\mathrm{CAT}(\mathrm{nmol} / \mathrm{mg} \\
\left.\text { protein } \cdot \mathrm{min}^{-1}\right)\end{array}$ & -0.35 & -0.46 & -0.35 & & \\
\hline $\begin{array}{l}\text { XOD }(\mu \mathrm{mol} / \mathrm{mg} \\
\left.\text { protein } \cdot \mathrm{min}^{-1}\right)\end{array}$ & $0.9^{* \% *}$ & 0.56 & 0.59 & -0.43 & \\
\hline $\begin{array}{l}\text { GSH-Px }(\mathrm{nmol} / \\
\text { mg protein.min }\end{array}$ & 0.63 & 0.05 & -0.03 & -0.22 & 0.38 \\
\hline
\end{tabular}


Table 2 - Correlation matrix of the studied parameters of oxidative stress in the livers of animals in the G group exposed to positive $(+7 \mathrm{Gz})$ acceleration ("p $<0.05$; $\left.{ }^{* * *} \mathrm{p}<0.01\right)$.

\begin{tabular}{|c|c|c|c|c|c|}
\hline +Gz group & $\begin{array}{l}\text { GSH (nmol/ } \\
\text { mg protein) }\end{array}$ & $\begin{array}{l}\text { LPx (nmol/mg } \\
\text { protein) }\end{array}$ & $\begin{array}{l}\operatorname{Px}(\mathrm{nmol} / \mathrm{mg} \\
\left.\text { protein } \cdot \mathrm{min}^{-1}\right)\end{array}$ & $\begin{array}{c}\mathrm{CAT} \\
\left(\mathrm{nmol} / \mathrm{mg}^{-1}\right. \\
\left.\text { protein } \cdot \mathrm{min}^{-1}\right)\end{array}$ & $\begin{array}{c}\text { XOD } \\
\left(\mu \mathrm{mol} / \mathrm{mg}^{-1}\right. \\
\text { protein·min })\end{array}$ \\
\hline $\begin{array}{l}\mathrm{LPx}(\mathrm{nmol} / \mathrm{mg} \\
\text { protein) }\end{array}$ & -0.19 & & & & \\
\hline $\begin{array}{l}\mathrm{Px}(\mathrm{nmol} / \mathrm{mg} \\
\left.\text { protein } \cdot \mathrm{min}^{-1}\right)\end{array}$ & -0.02 & 0.16 & & & \\
\hline $\begin{array}{l}\mathrm{CAT}(\mathrm{nmol} / \mathrm{mg} \\
\left.\text { protein } \cdot \mathrm{min}^{-1}\right)\end{array}$ & -0.14 & 0.4 & 0.19 & & \\
\hline $\begin{array}{l}\text { XOD }(\mu \mathrm{mol} / \mathrm{mg} \\
\left.\text { protein } \mathrm{min}^{-1}\right)\end{array}$ & -0.05 & 0.47 & 0.48 & -0.11 & \\
\hline $\begin{array}{l}\text { GSH-Px }(\mathrm{nmol} / \mathrm{mg} \\
\left.\text { protein } \cdot \mathrm{min}^{-1}\right)\end{array}$ & 0.19 & -0.10 & 0.09 & $-0.71^{*}$ & 0.18 \\
\hline
\end{tabular}

\section{Pathological morphological analysis}

In the control and experimental groups, macroscopic and microscopic changes were observed in the heart, liver and gastric tissues.

In the livers of the animals in the experimental group, macroscopic alterations were not observed, while significant microscopic changes were observed in the liver tissue. The liver cells showed unclear boundaries, strong hyperaemia expression, vacuolysed cells and a high volume of liquids reflecting degenerative changes (Fig. 3). The blood vessels were filled with compacted platelets, reminiscent of thrombotic changes. A large, organized thrombus was observed in the lumen of an artery. Inflammatory lesions, including lymphocytic infiltration, granuloma, macrophage aggregates and variable glycogen content, were not observed in the hepatic tissues of animals in the experimental group. Generally, hepatic parenchyma showed moderate interstitial haemorrhages (Fig. 4).

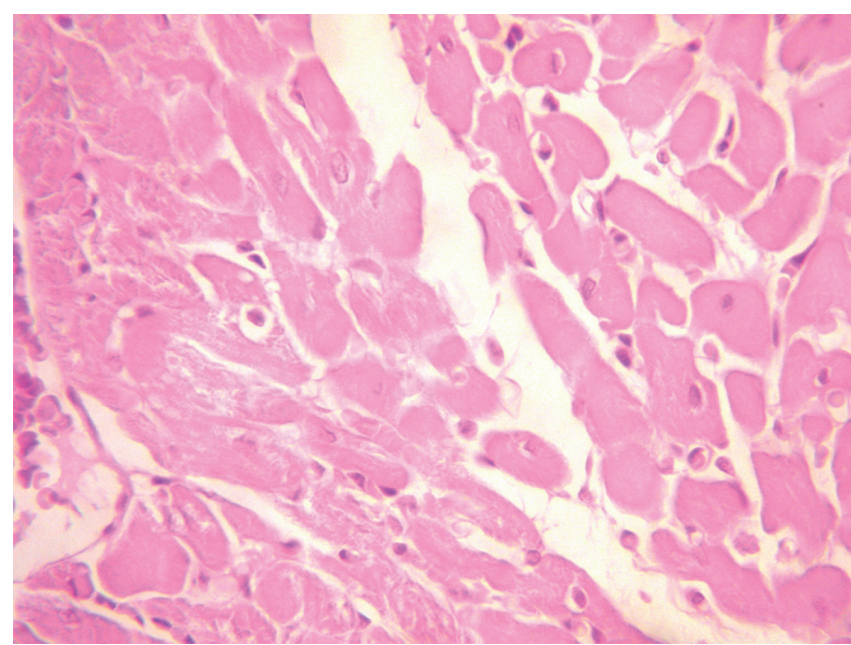

Fig. 3 - Macroscopic appearance of the livers of animals exposed to positive $(+7 \mathrm{Gz})$ acceleration (magnification $10 \mathrm{x}$ )
In the heart tissue of the experimental group, significant macroscopic alterations were not observed, compared to healthy animals. However, in histological preparations of the heart, we observed altered and unclear cell borders, with the loss of the transverse leaf striping in the vertical direction (Fig. 5). These microscopic myocardial lesions were mild and nonspecific and did not contribute to an aetiological diagnosis of the cardiac disease.

Gastric mucosa from the control group showed that the epithelium was intact, and the cells had no hyperaemia and oedema, and the submucosa and muscularis contained no inflammatory cells. In five of the ten animals exposed to positive $(+7 \mathrm{Gz})$ stress, we observed significant macroscopic changes in the gastric mucosa, with a total ulcer index of $\mathrm{UI}=1.54 \mathrm{~mm} \pm 0.02$ and a score of 2 (Fig. 6). Moreover, the stress-induced gastric ulcers in the experimental group showed that the structure of the gastric mucosa was completely damaged, with gastric gland cell necrosis, cells displaying hyperaemia and oedema, and several inflamma-

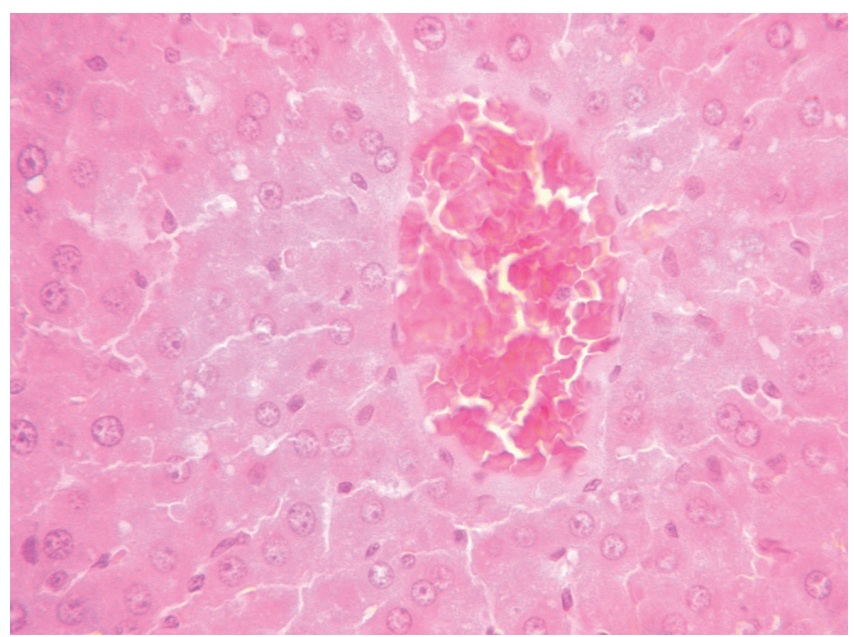

Fig. 4 - Microscopic appearance of the livers of animals exposed to positive $(+7 \mathrm{Gz})$ acceleration (magnification $100 \mathrm{x}$ ) 


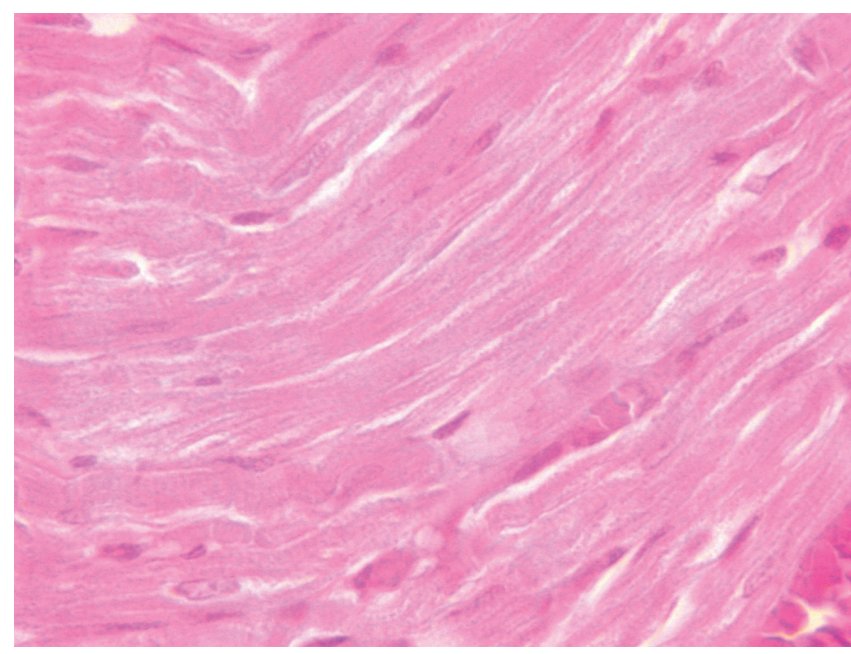

Fig. 5 - Microscopic appearance of the hearts of animals exposed to positive $(+7 \mathrm{Gz})$ acceleration (magnification 100x)

tory cells infiltrating the mucosa, submucosa and muscularis (Fig. 7).

\section{DISCUSSION}

The objective of the present study was to reveal the effects, including morphological effects, and investigate the role of antioxidative enzyme system under biodynamic stress in the liver, heart and gastric mucosa as a result of high-magnitude $+\mathrm{Gz}$ exposure in a rat model.

In the present study, we examined the influence of acute biodynamic stress $(+7 \mathrm{Gz})$ on the dynamics of the parameters of oxidative stress in the liver, such as enzyme activity of xanthine oxidase (XOD), catalase (CAT), peroxidase $(\mathrm{Px})$, glutathione peroxidase (GSH-Px), total content of glutathione (GSH), lipid peroxidation (LPx) and histopathological alterations in the liver, cardiac muscle and the mucosa of the stomach.

Initially, we examined the effect of positive acceleration on CAT activity, GSH content and GSH-Px. We observed significantly increased CAT and GSH-Px activity in the experimental group, whereas there was a statistically significant negative correlation between these two parameters.

As the catalase (CAT) enzyme is involved in the degradation of $\mathrm{H}_{2} \mathrm{O}_{2}$ into water and oxygen, we assumed that in the state of the positive $(+\mathrm{Gz})$ acceleration generated large amounts of hydrogen peroxide (34). This idea was confirmed by the increased activity of GSH-Px, which by other metabolic pathways, in cooperation with GSHR, reduces hydrogen peroxide into water. This reduction of hydrogen peroxide was followed by the conversion of the reduced form of glutathione (GSH) into the oxidized form (GSSG) $(22,34)$. In addition, the increased activity of catalase (CAT), as an enzyme for antioxidant protection, was observed in the liver of rats exposed to immobilization stress, alcoholic stress (99\% ethanol) and stress induced by indomethacin, while the activity of GSH-Px in these three stress models was reduced in the liver (30-32).

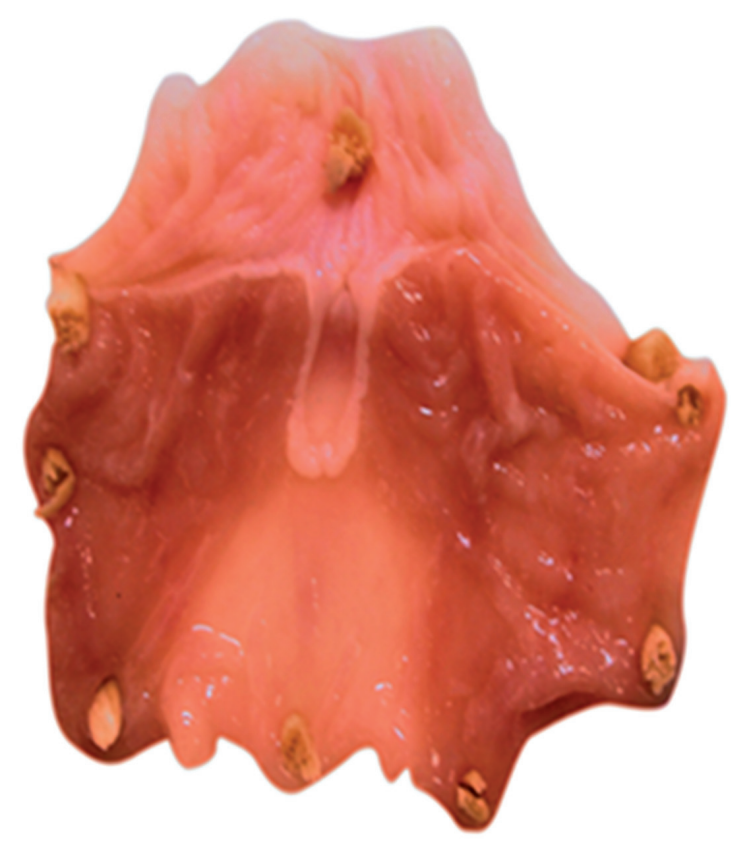

Fig. 6 - Macroscopic appearance of the gastric mucosa of animals exposed to positive $(+7 \mathrm{Gz}$ ) acceleration (magnification 10x)

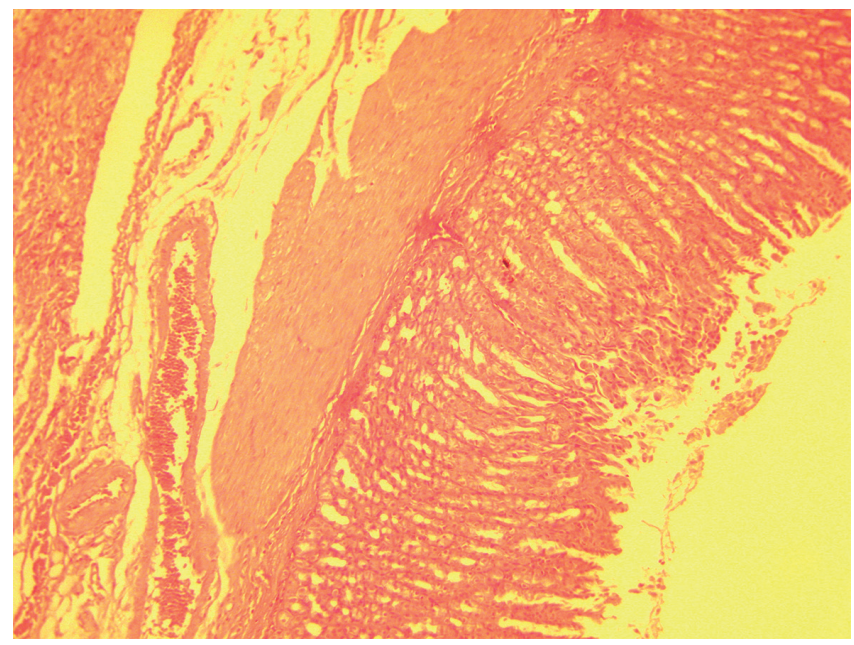

Fig. 7 - Microscopic appearance of the gastric mucosa of animals exposed to positive $(+7 \mathrm{Gz}$ ) acceleration (magnification $100 \mathrm{x}$ )

The levels of GSH were decreased, but not significantly, likely reflecting the increased activity of GSH-Px, which was not be able to significantly "spend" reduced glutathione. Important non-enzymatic compounds of protection, such as GSH in the liver, were not changed compared to the control group, and under acute stress the protective role of these compounds was confirmed. Chen $L$ et al investigated the effects of high-sustained positive acceleration $(+\mathrm{Gz})$ for 15 days on rats. Interestingly, the activities of its antioxidant enzymes SOD and GSH-Px were decreased but the formation of malondialdehyde (MDA) was increased (24). These results are not consistent with the results of the present study, and the difficulty in interpreting experimental data on animals 
(mice and rats) lies in the diversity of these experiments (the diversity of additional substances, which show different properties, different mice/rats by sex and age, duration of $+\mathrm{Gz}$ exposing, level used, type and scope). Thus, acute biodynamic stress induced by positive acceleration $(+7 \mathrm{Gz})$ is likely insufficient to significantly induce decreased levels of antioxidant enzymes, such as GSH (24).

Generally, acute stress resulting from acceleration at high amplitude in exposed organism directly disturbs proper cell functioning, leading to vessel collapse and multiple organ ischaemia. Indeed, these processes are similar to those of ischaemia and reperfusion, as a major generator of reactive oxygen species (37). During the stress of positive acceleration forces, resulting in many ischaemia/reperfusion injuries, it is important to evaluate the levels of antioxidant enzymes, such as the enzymes mentioned above.

Thus, cytosolic xanthine oxidase has been considered for many years as the main source of superoxide anion during the reperfusion of ischaemic tissues. Many authors have proposed that the mechanism of post-ischaemic reperfusion damage is mediated by xanthine oxidase (36). In the present study, the levels of Px and XOD were not significantly changed compared to control conditions, and this finding confirms that the acute stress induced by acceleration for 40 seconds did unlikely generate significant ROS production, and under these conditions, the liver likely does not suffer oxidative stress.

Furthermore, levels of lipid peroxidation (LPx) were significantly decreased compared to the control, which was positively correlated with Px activity in the control group. Little is known about the acute effects of $+\mathrm{Gz}$ stress on lipid peroxidation; thus, it is difficult to compare these results with the results of other authors. Zhang et al described the importance of changes in the dynamic of LPx in various organs of rats exposed to chronic high $+\mathrm{Gz}$ stress $(+10 \mathrm{Gz})$ for three weeks. This study showed significantly increased concentration of MDA in mitochondria infarction after exposure to $+10 \mathrm{Gz}$-in, while the activity of SOD in liver homogenates and mitochondria in the kidney was significantly reduced, but repeated $+10 \mathrm{Gz}$ acceleration increased mitochondria LPx in hearts and affected the metabolism of free radicals in the liver and kidneys of rats (25). Moreover, Zhan et al investigated the effects of repeated $+10 \mathrm{Gz}$ stress on cerebral lipid peroxidation, liver and renal function in rats. These authors showed that the lipid peroxidation in rat cerebral homogenate, mitochondria and cytoplasm was significantly increased (29). These results indicated that repeated high $+\mathrm{Gz}$ stress could induce peroxidative injury in the brain and generate harmful effects on renal function. Thus, chronic biodynamic stress can induce more deleterious effects on the lipid components of the membrane compared to acute $+\mathrm{Gz}$ stress (25).

To completely evaluate the effects of acute $+\mathrm{Gz}$ acceleration, we observed macroscopic and microscopic alterations in the liver, heart and gastric tissue of rats. There is limited data concerning the morphological changes in different organs and tissues (liver and heart) under high posi- tive acceleration, and it is difficult to compare the results of the present study with those of other studies. We detected significant microscopic changes in all tissue samples mentioned above, but macroscopic changes were verified only in the gastric mucosa. $\mathrm{Li} J$ and co-workers studied the impacts of positive acceleration $(+\mathrm{Gz})$ on the gastric mucosal tissues in cases of acute gastric mucosal injury and explored the role of oxygen free radicals (27). The results suggested that $+\mathrm{Gz}$ exposure might aggravate the acute gastric mucosal injury, and changes in MDA and SOD contents in the gastric tissues indicated that the oxygen free radicals play an important role in this regard. The authors also concluded that the damage increased with increasing positive acceleration (27). Some authors investigated the role of the exogenous administration of antioxidant enzymes under positive acceleration $(+5$ and $+10 \mathrm{Gz})$ on gastric mucosal tissues and concluded that this pretreatment reduces gastric mucosal injury (28).

Thus, the basic question is whether these antioxidant enzymes are indicators of oxidative stress and damage in the liver, heart or gastric mucosa?

In healthy animals with no macroscopic and microscopic alterations, the levels of Px activity were positively correlated with the levels of LPx. In the experimental group, the activity of these parameters was changed, and the activity of LPx was decreased while the activity of Px was insignificantly increased, with significant micro and macroscopic alterations in the mentioned tissues. To our knowledge, peroxidases (Px) are enzymes localized in cellular organelles, such as peroxisomes, which is also the location of many reactive oxygen species (ROS) (34, 35). Under acute stress, we expected increased ROS and Px production, consistent with the results of the present study. However, the LPx level was paradoxical decreased, likely reflecting short-term biodynamic stress, while repeated stress induced increased levels of LPx (29).

Under oxidative stress, we expected the increased activity of all antioxidant enzymes, such as GSH, CAT, XOD and GSH-Px, but the duration of the stress period was definitely a limiting factor in the present study. GSH activity was unexpectedly decreased, and the levels of other enzymes were insignificantly increased. Interestingly, these primarily enzymatic changes are excellent indicators of tissue damage but are not specific, as the values of parameters confirm the existence of damage but do not explain the extent and type of damage.

However, it is important to know the mechanisms by which positive acceleration induces harmful effects on different cells in organisms. Exposure to high-sustained positive acceleration $(+\mathrm{Gz})$ has a pathophysiological effect on the heart of the rat. As critical regulators of cardiac myocyte survival and death, mitochondria may be crucially involved in $+\mathrm{Gz}$-induced pathogenesis (33-37). Chen and co-workers investigated myocardial mitochondrial ultrastructure, respiratory function, and antioxidant capacity in rats after exposure to $+10 \mathrm{Gz}$ for $5 \mathrm{~min}$ (33). The results showed that high $+\mathrm{Gz}$ stress could damage the mitochondrial ultrastruc- 
ture, evidenced as swollen, degenerated, and reduced mitochondria, and broken or disappeared mitochondrial cristae. These effects resulted in significant changes in quantitative indicators of mitochondria morphometry, for example increased surface density, volume density, average volume, and average surface area, and reduced numerical density. Other studies have also revealed that exposure to $+\mathrm{Gz}$ stress induced the dysfunction of the mitochondrial respiratory chain, reduced the activity of antioxidant enzymes (catalase, superoxide dismutase, and glutathione peroxidase), and increased the malondialdehyde content (30-37).

\section{CONCLUSION}

The results of the present clearly indicate that $+\mathrm{Gz}$ acceleration alters biochemical systems. However, these results tend to suggest that these alterations in cellular processes may be mediated by influences other than hypoxia or ischaemia via changes in the antioxidant capacity.

However, the molecular mechanisms by which oxidative stress is produced and the time course of the phenomenon remain unclear, and additional studies with repeated or chronic biodynamic stress after acute biodynamic stress are necessary to clearly explain and provide more precise answers concerning the mechanisms and dynamics of antioxidant enzymes in oxidative stress induced by positive acceleration.

\section{REFERENCES}

1. Lauritzsen LP, Pfitzner J. Pressure breathing in fighter aircraft for $\mathrm{G}$ accelerations and loss of cabin pressurization at altitude--a brief review. Can J Anaesth. 2003;50(4):415-9.

2. Fong KL, Fan SW. An overview of the physiological effects of sustained high $+\mathrm{Gz}$ forces on human being. Ann Acad Med Singapore. 1997; 26(1):94-103.

3. Convertino VA. High sustained $+\mathrm{Gz}$ acceleration: physiological adaptation to high-G tolerance. J Gravit Physiol. 1998; 5: P51-54

4. Stevenson AT, Scott JP, Chiesa S, Sin D, Coates G, Bagshaw M, Harridge S.Blood pressure, vascular resistance, and $+\mathrm{Gz}$ tolerance during repeated $+\mathrm{Gz}$ exposures. Aviat Space Environ Med. 2014; 85(5):536-42.

5. Burton RR, Leverett SD Jr, Michaelson ED. Man at high sustained $+\mathrm{Gz}$ acceleration: a review. Aerosp Med. 1974; 45(10):1115-36.

6. Lu WH, Hsieh KS, Li MH, Ho CW, Wu YC, Ger LP, Wang JS, Chu H. Heart statusfollowing high G exposure in rats and the effect of brief preconditioning. AviatSpace Environ Med. 2008; 79(12):1086-90.

7. Wan X-S, Ware J-H, Zhou Z, et al. Protection against radiation-induced oxidative stress in cultured human epithelial cells by treatment with antioxidant agents. Int J Radiat Oncol Biol Phys. 2006; 64:1475-81.
8. Koppula S, Kumar H, Kim I-S, et al. Reactive oxygen species and inhibitors of inflammatory enzymes, NADPH oxidase, and iNOS in experimental models of Parkinson's disease. Mediators Inflamm. 2012; 65:1400-15.

9. Aruoma O-I. Free radicals, oxidative stress, and antioxidants in human health and disease. J Am Oil Chem Soc. 1998; 75:199-218.

10. Zhou Y, Wang B, Wang YC, Wu YH, Zhang S, Geng J, Sun XQ. [Apoptosis in myocyte after repeated $+\mathrm{Gz}$ exposures in rats]. Zhongguo Ying Yong Sheng Li Xue Za Zhi. 2010; 26(3):275-7.

11. Mapp P-I, Grootveld M-C, Blake D-R. Hypoxia, oxidative stress and rheumatoid arthritis. Br Med Bull. 1995; 51:419-36.

12. Gonzalez Flecha, B., S. Llesuy, and A. Boveris. 1991. Hydroperoxide-initiated chemiluminescence: an assay for oxidative stress in biopsies of liver, heart and muscle. Free Radical Biol. Med. 10:93-100.

13. Benzie I.F.F., Strain J.J. Feric reducing antioxidant power assay: Direct measure of total antioxidant activity of biological fluids and modified version for simultaneous measurement of total antioxidant power and ascorbic acid and concentration. Methods Enzymol. 1999; 299:15-17.

14. Flohe, L., and W. A. Gunzler. Assays of glutathione peroxidase. Methods Enzymol. 1984; 105:114.

15. Wendel A Enzymatic basis of detoxication. New York Academic Press. 1980; pp 333

16. Vives-Bauza C, Starkov A, Garcia-Arumi E. Measurements of the antioxidant enzyme activities of superoxide dismutase, catalase, and glutathione peroxidase. Methods Cell Biol. 2007; 80:379-393 .

17. Blum J, Fridovich I. Inactivation of gluthathione peroxidase by superoxide radical. Arch Biophys. 1985; 240:500.

18. Bergmayer UH. Methoden Der Enzymatischen Analyse. Verlag Chemies, Weinhem, 1970; 483-484,.

19. Hodges GR, Young MJ, Paul T, Ingold KU. How shoud xanthine oxidase generated superoxide yields be measured? Free Radical Bio-logy \& Medicine. Vol.29, No. 5:434-441, 2000.

20. Halliwell B., Chirico, S. Lipid peroxidation: its mechanism, measurement and significance, Am. J. Clin. Nutr., 1993; 57:715S-725S.

21. Fischer AH, Jacobson KA, Rose J, Zeller R. Hematoxylin and eosin staining of tissue and cell sections. CSH Protoc. 2008; 49-86.

22. Histopathological alteration of the rat myocardium exposed to repeated high +Gz Biomed Res. 2012; 23: 375-379.

23. Guth PH, Aures D, Paulsen G. Topical aspirin plus $\mathrm{HCl}$ gastric lesions in the rat. Cytoprotective effect of prostaglandin, cimetidine, and probanthine. Gastroenterology. 1979; 76(1):88-93.

24. Chen LE, Wu F, Xin YM, Zhao AD, Wang YX, Zhan H. Protective effect of Tianqi Hangli Recipe extract on high sustained positive acceleration stress-induced myocardial mitochondrial injury in rats. Chin J Integr Med. 2014; 54-65. 
25. Zhang Z., Zhan H., Geng X C. The progress on $+\mathrm{Gz}$ stress-induced injuries of the cardiac structure and function and their mechanisms; Space Med Med Eng. 2001; 14:378-81.

26. Markin A, Juravlyova O, Lukianuk V. Lipid peroxidation and the system of antioxidant defence in humans after hypergravitational influence. J Gravit Physiol. 2004;11(2):P69-70.

27. Li J, Tang HL, Chen Y, Fan Q, Shao YT, Jia M, Wang JC, Yang CM. Malondialdehyde and SOD-induced changes of gastric tissues in acute gastric mucosal injury under positive acceleration. Genet Mol Res. 2015; 14(2):4361-8.

28. Shao YT, Li J, Chen Y, Yang CM, Tang HL, Wang JC. [Effects of glutathione on plasma heat shock protein 70 of acute gastric mucosal injury in rats exposed to positive acceleration]. Zhonghua Yi Xue Za Zhi. 2013; 93(46):3708-10.

29. Zhan H, Chen LM, Xin YM, Tang GX, Wen J. Effects of tea polyphenols on cerebral lipid peroxidation, liver and renal functions in rats after repeated $+\mathrm{Gz}$ stress. Space Med Med Eng. 1999; 12(1):1-5.

30. Chen LE, Wu F, Xin Y, Zhao A, Sun X, Zhan H. Effect of high sustained $+\mathrm{Gz}$ stress on myocardial mitochon- drial ultrastructure, respiratory function, and antioxidant capacity in rats. J Physiol Sci. 2013; 63(6):457-64.

31. Burton RR, Jaggars JL. Influence of ethyl alcohol ingestion on a target task during sustained $+\mathrm{Gz}$ centrifugation. Aerosp Med. 1974; 45(3):290-6.

32. Burns JW. Influence of ethanol on cardiovascular tolerance to + Gz acceleration. Aerosp Med. 1974; 45(1):19-28.

33. Chen XY, Chen HM, Liu YH, Zhang ZB, Zheng YF, Su ZQ, Zhang X, Xie JH, Liang YZ, Fu LD, Lai XP, Su ZR, Huang $X Q$. The gastroprotective effect of pogostone from Pogostemonis Herba against indomethacin-induced gastric ulcer in rats. Exp Biol Med (Maywood). 2016; 241(2):193-204.

34. Yang HY, Lee TH. Antioxidant enzymes as redox-based biomarkers: a brief review. BMB Rep. 2015; 48(4):200-8.

35. Lushchak VI. Free radicals, reactive oxygen species, oxidative stresses and their classifications. Ukr Biochem J. 2015; 87(6):11-8.

36. Labat-Robert J, Robert L. Longevity and aging. Role of free radicals and xanthine oxidase. A review. Pathol Biol (Paris). 2014; 62(2):61-6.

37. Higashi Y, Maruhashi T, Noma K, Kihara Y. Oxidative stress and endothelial dysfunction: clinical evidence and therapeutic implications. Trends Cardiovasc Med. 2014; 24(4):165-9. 